\title{
Paediatric spinal trauma. When in doubt, scan again
}

\author{
Barry James O'Neill, Darren F Lui, Mary Nugent, Patrick John Kiely
}

Department of Trauma \& Orthopaedics, Our Lady's Children's Hospital, Dublin, Ireland

\section{Correspondence to}

Barry James O'Neill, barryoneill1922@gmail.com

Accepted 9 February 2014

\section{DESCRIPTION}

A 9-year-old boy was a restrained back-seat passenger in a road traffic accident. He was assessed in the local hospital, where CT scans of his spine demonstrated undisplaced fractures of $\mathrm{C} 1$ and $\mathrm{C} 2$ vertebrae, and chance fracture of L1 vertebra with obliteration of the spinal canal (figure 1). He was transferred to a specialist paediatric unit for further assessment and management. Clinical examination revealed tenderness at the craniocervical and thoracolumbar junctions, but neurological examination was normal in all four limbs (American Spinal Injury Association (ASIA) score E). ${ }^{1}$ The lower limb findings were felt to be inconsistent with the radiological imaging, and a repeat
CT was arranged (figure 2). The repeat CT and an MRI confirmed that no significant spinal injury had occurred. After further review of the case history, it was elucidated that the child had been distressed at the time of the initial CT, and had been crying when the images were taken. Subsequent review of the initial scans demonstrated subtle evidence of movement artefact at the craniocervical and thoracolumbar junctions. When clinical findings and radiological imaging are inconsistent or contradictory, repeat imaging is recommended, especially in the case of suspected major trauma in children. Repeat imaging in this case prevented a 9-year-old boy from undergoing an unnecessary spinal surgery.

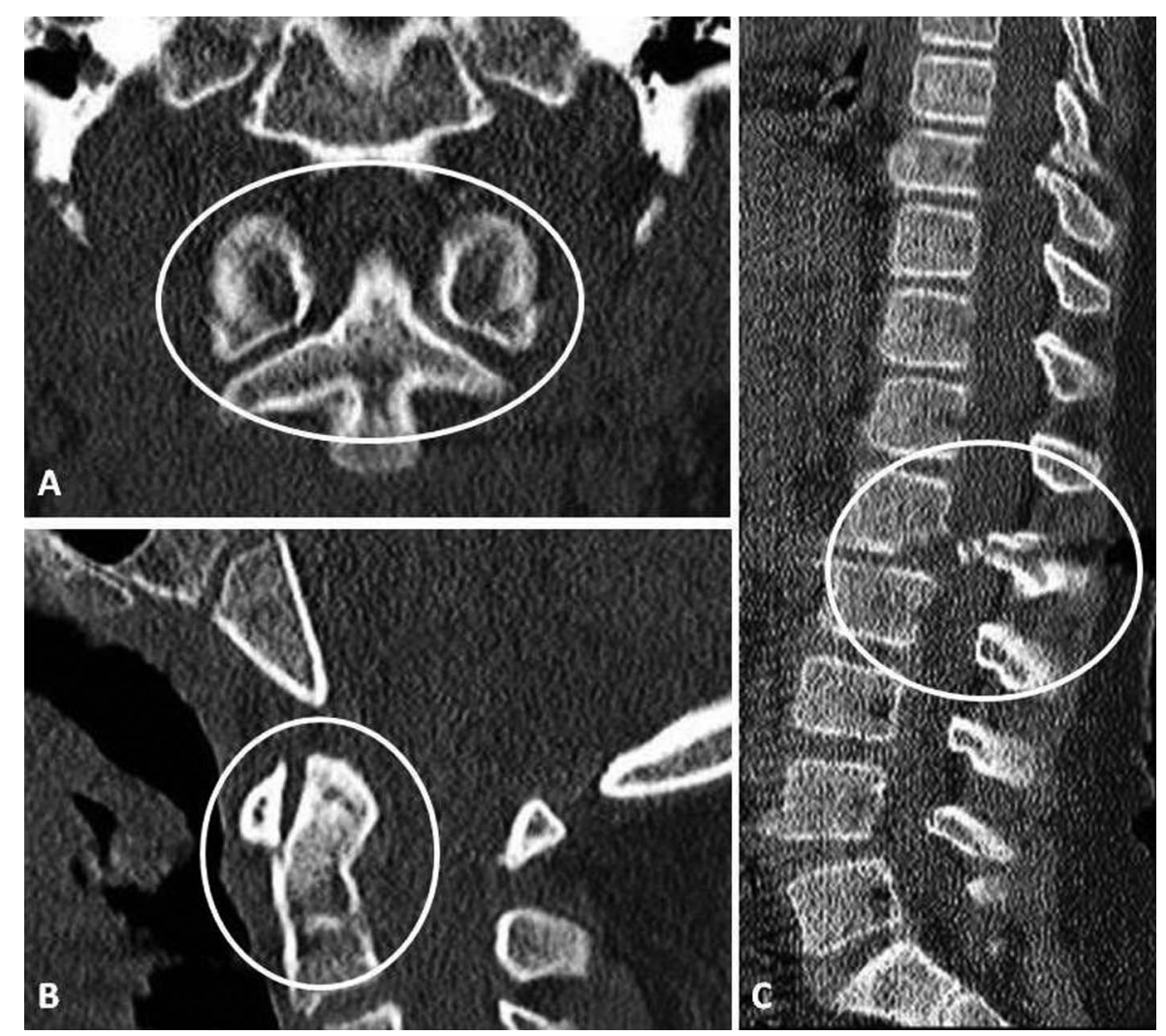

Figure 1 Initial CT scans from peripheral institution seemingly demonstrating fracture of odontoid peg (A), fracture of right lateral mass of $\mathrm{C1}(\mathrm{B})$ and bony chance fracture of $\mathrm{L} 1$ with obliteration of the spinal canal (C). 


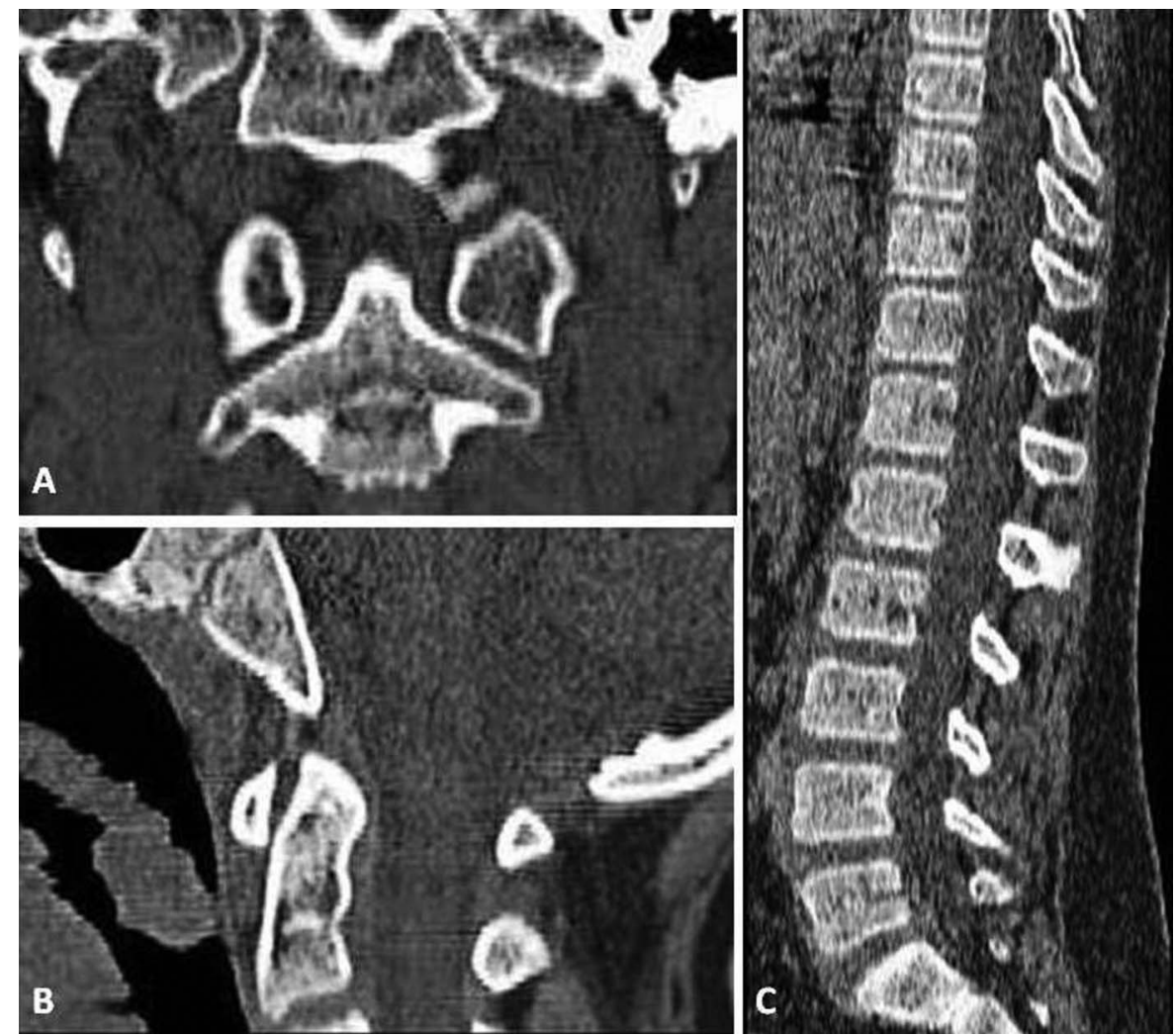

Figure 2 Repeat CT scans with similar cuts demonstrating no evidence of fracture in C2 (A), C1 (B) or L1(C). These findings were further confirmed with MRI of same areas.

\section{Learning points}

- Major trauma in children can be stressful for the patient, the family and the medical team.

- Never value investigative results over a thorough history and clinical examination.

- When clinical findings are inconsistent with investigation results, do not hesitate to review the clinical findings and repeat the investigations. proofread the manuscript. MN edited the images, proofread the manuscript and arranged parental consent for the use of the images. PJK is the consultant with overall responsibility for the case, and proofread and approved the final manuscript and images.

Competing interests None.

Patient consent Obtained.

Provenance and peer review Not commissioned; externally peer reviewed.

\section{REFERENCE}

1 Marino RJ, Barros T, Biering-Sorensen F, et al. International standards for neurological classification of spinal cord injury. J Spinal Cord Med 2003;26(Suppl 1):S50-6.

Contributors BON was the receiving surgeon when the patient was transferred. BON wrote the manuscript and prepared the images. DFL arranged the repeat scans and

Copyright 2014 BMJ Publishing Group. All rights reserved. For permission to reuse any of this content visit http://group.bmj.com/group/rights-licensing/permissions.

BMJ Case Report Fellows may re-use this article for personal use and teaching without any further permission.

Become a Fellow of BMJ Case Reports today and you can:

- Submit as many cases as you like

- Enjoy fast sympathetic peer review and rapid publication of accepted articles

- Access all the published articles

- Re-use any of the published material for personal use and teaching without further permission

For information on Institutional Fellowships contact consortiasales@bmjgroup.com

Visit casereports.bmj.com for more articles like this and to become a Fellow 